\title{
Bakteriofag spesifik Escherichia coli yang diisolasi dari berbagai sumber air di Bogor Tengah, Kota Bogor sebagai antibiotika alternatif
}

\author{
Escherichia coli specific bacteriophage isolated from various water sources in Central \\ Bogor, Bogor City as an alternative antibiotic
}

\author{
Arga Darmawan Wally ${ }^{1 *}$, Eko S. Pribadi ${ }^{2}$, Surachmi Setyaningsih $^{2}$ \\ 1) Program Studi Mikrobiologi Medik \\ Departemen Ilmu Penyakit Hewan dan Kesehatan Masyarakat Veteriner, Fakultas Kedokteran Hewan, Institut Pertanian \\ Bogor, Bogor Jawa Barat 16680 \\ ${ }^{2)}$ Divisi Mikrobiologi Medik \\ Departemen Ilmu Penyakit Hewan dan Kesehatan Masyarakat Veteriner, Fakultas Kedokteran Hewan, Institut Pertanian \\ Bogor, Bogor Jawa Barat 16680 \\ *Email: argaeducation@gmail.com
}

Diterima 24 Desember 2020

Disetujui 10 November 2021

\section{INTISARI}

Penelitian ini bertujuan untuk melakukan isolasi faga spesifik Escherichia coli pada beberapa titik contoh air di Bogor Tengah Kota Bogor dan menyimpannya. Penelitian dilakukan di Kota Bogor pada bulan Maret dan April 2020. Pengkayaan faga dilakukan dua kali sebagai metode baku (gold standard) mengisolasi faga. Uji plak dilakukan untuk mengukuhkan adanya faga di dalam contoh air yang diperiksa menggunakan filtrat yang diperoleh dari metode pengkayaan faga. Hasil yang diperoleh dalam Penelitian ini adalah isolat E. coli yang diisolasi dalam semua contoh air dan faga yang hanya diperoleh satu contoh air, yakni air celupan daging Pasar Merdeka Kota Bogor. kandungan faga dalam contoh air sebesar 9,1 x 10 8 PFU/ml. Kadar faga tersebut dinilai cukup tinggi yang berpotensi digunakan pada terapi terhadap infeksi bakteri yang disebabkan oleh E. coli.

Kata kunci: Escherichia coli, air, faga, uji plak

\begin{abstract}
The Research isolated specific phages of Escherichia coli in various water sample in Bogor Tengah, Bogor City and stored them. The Research was conducted in Bogor City in March and April 2020. Phage enrichment was carried out twice as the gold standard method of isolating phages. The plaque test was carried out to confirm the presence of phages in the collected water samples examined using the filtrate obtained only from the phage enrichment method. E. coli isolated in all water samples and phage obtained one water sample, namely the meat dyeing of Pasar Merdeka, Bogor City. The phage concentration in the water sample was $9.1 \times 10^{8} \mathrm{PFU} / \mathrm{ml}$. The phage concentration level was considered high enough that it has the potential to be used in the therapy of bacterial infections caused by E. coli.
\end{abstract}

Keywords: Escherichia coli, water, phage, plaque test 


\section{PENDAHULUAN}

Dalam dekade terakhir ini, telah terlihat peningkatan drastis jumlah bakteri patogen yang tahan terhadap sejumlah obat antibakteri. Bakteri yang tahan terhadap obat-obatan saat ini dianggap sebagai masalah global yang muncul dan sebagai masalah kesehatan masyarakat yang utama, termasuk di Indonesia (Utami, 2012). Tahan terhadap antimikroba (antimicrobial resistance, AMR) merupakan ancaman serius di dunia kesehatan. Angka kematian karena AMR di dunia pada tahun 2014 mencapai 700.000 orang pertahun dan angka ini diperkirakan akan meningkat drastis menjadi 10 juta orang pertahun di tahun 2050. Sedangkan di Asia, angka kematian diperkirakan akan mencapai 4,6 juta pertahun (O’Neill, 2014).

Tahan terhadap mikroorganisme dapat terjadi karena penggunaan antimikroba yang berulang. Hal ini dikarenakan adanya paparan penggunaan antibakteri yang tidak tepat dan terkendali yang memberikan tekanan terjadinya kenaikan dan penyebaran sejumlah bakteri yang tahan terhadap antibiotika. Sebagai contoh, terjadi kegagalan pengobatan dengan sefalosporin generasi ketiga yang merupakan lini terakhir untuk pengobatan gonorea, terjadi ketahanan terhadap fluorokuinolon yang merupakan obat oral yang terbanyak digunakan untuk infeksi saluran kemih oleh Escherichia coli dan terjadi ketahanan berbagai kuman enterik terhadap karbapenem (WHO, 2014).

Bakteriofaga, atau faga adalah virus yang menginfeksi bakteri. Faga dapat menginfeksi dan melisiskan sel bakteri dengan metode pelepasan bahan genetiknya ke dalam sitoplasma sel bakteri dan bersifat khusus terhadap galur bakteri tertentu, atau terhadap beberapa galur bakteri sekaligus. Hal ini yang menyebabkan faga dianggap sebagai salah satu jalan keluar yang dapat mengatasi masalah ketahanan bakteri terhadap antimikroba yang terjadi di dunia saat ini dengan penggunaan terapi faga dalam menyembuhkan infeksi yang disebabkan oleh bakteri (Lin et al., 2017).
Faga memiliki reseptor khusus terhadap bakteri tertentu, tidak bersifat toksik di lingkungan kecuali terhadap bakteri yang diinfeksinya, dan jumlah serta keragaman yang tinggi menjadikan faga dianggap cocok sebagai antibiotika pilihan. Penggunaan beragam faga dapat mengendalikan penyakit infeksi yang disebabkan oleh beragam bakteri (Chan et al., 2013). International Committee on Taxonomy of Viruses (ICTV) mengelompokkan faga berdasarkan susunan dan asam nukleat virus. Ada lebih dari 5500 jenis faga di planet ini sehingga dianggap sebagai virus dengan jumlah terbanyak yang ada saat ini (Ackermann, 2012). Faga yang menghasilkan enzim polysakarida lyase yang khusus dengan jumlah kadar tertentu memiliki tindakan pencegahan, penghambatan, dan penurunan lapisan hayati (biofilm) E. coli (Triana, 2018). Penelitian ini mengisolasi faga khusus E. coli dari contoh air di berbagai sumber di Bogor Tengah Kota Bogor yang dimasa mendatang dapat digunakan untuk terapi infeksi bakteri.

\section{BAHAN DAN METODE}

\section{Tempat dan Waktu Penelitian}

Penelitian ini dilakukan pada bulan Maret dan April 2020 di Laboratorium Terpadu Mikrobiologi Fakultas Kedokteran Hewan Institut Pertanian Bogor, Bogor.

\section{Pengambilan Contoh Air}

Contoh air diambil di enam titik di Bogor Tengah, yaitu tiga titik berbeda di Sungai Ciliwung (koordinat -6.602474,106.802465; $6.590798,106.799116 ; \quad-6.586015,106.798230$ ), satu titik air minum hewan, satu titik air ikan hidup, dan satu air celupan daging di Pasar Merdeka Kota Bogor (koordinat 6.592230,106.786172). Pengambilan contoh air minum hewan didasarkan dugaan pencemaran $E$. coli dari feses burung dan dugaan terdapatnya faga. Begitu juga dengan air ikan hidup yang dijual di Pasar Merdeka diduga mengandung $E$. coli dan juga faga pada airnya. Sementara air celupan daging terlihat sangat keruh dan kotor sehingga diduga mengandung $E$. coli dan faga. 
Sebanyak kurang lebih 40-100 ml contoh air diambil menggunakan wadah steril dan disimpan pada kotak pendingin dan dibawa ke laboratorium untuk pengujian selanjutnya.

\section{Isolasi dan Persiapan Biakan $E$. coli}

Contoh air diencerkan secara desimal hingga pengenceran $10^{-4}$ menggunakan Sodium Chloride $^{\circledR}(\mathrm{NaCl}$, Merck). Sebanyak 1,0 ml dari masing-masing pengenceran ditempatkan ke permukaan media Eosin Methylene Blue Agar ${ }^{\circledR}$ (EMBA, Oxoid) dan disebarkan secara merata. Media yang telah diberi contoh air diinkubasi semalam pada suhu $37{ }^{\circ} \mathrm{C}$. Koloni positif E. coli yang tumbuh di atas media EMBA dibiakkan ke atas agar datar Tryptone Soya Agar ${ }^{\circledR}$ (TSA, Oxoid) dan Mac Conkey Agar ${ }^{\circledR}$ (MCA, Oxoid), serta disimpan pada media agar miring TSA sebagai penyimpanan isolat bakteri jangka panjang pada suhu $4{ }^{\circ} \mathrm{C}$. Persiapan biakan murni E. coli dari media TSA diremajakan dengan metode gores kuadran di media agar datar TSA dan lalu diinkubasi selama 24 jam pada suhu 35 ${ }^{\circ} \mathrm{C}$ sebelum digunakan pada pengkayaan faga. Sementara untuk uji penegasan $E$. coli dilakukan pewarnan Gram dan uji indol, merah metil (methyl red), voges proskauer, dan sitrat (citrate) (IMViC) (Ulfah et al., 2017; Kartikasari et al., 2019).

\section{Pengkayaan dan Isolasi Faga}

Pengkayaan faga dilakukan sebanyak dua kali. Sebanyak $40 \mathrm{ml}$ contoh air dicampur dengan $5 \mathrm{ml}$ Luria Bertani (LB) $1 \%$ dan $5 \mathrm{ml}$ biakan bakteri $E$. coli yang telah diremajakan semalam. Larutan diinkubasi selama 24 jam suhu $37{ }^{\circ} \mathrm{C}$ pada alat pengocok (shaker) dengan kecepatan 100 rotation per minutes (rpm). Sebanyak $10 \mathrm{ml}$ suspensi setelah masa inkubasi dicapai dipindahkan ke tabung sentifus dan disentrifugasi pada kecepatan 2000 rpm selama lima menit (Rahaju, 2014). Supernatan diambil dan disaring menggunakan membran penyaring suci hama $0,22 \mu \mathrm{m}$ sebagai Filtrat I. Pengkayaan kedua untuk mendapatkan Filtrat II dilakukan dengan teknik yang sama. Filtrat disimpan pada suhu $4{ }^{\circ} \mathrm{C}$ (Damayanti et al., 2016).

\section{Uji Plak (Plaque Assay) dan Penyimpanan Faga}

Uji plak dilakukan untuk mengetahui ada tidaknya faga pada contoh yang diuji serta menghitung kadar faga. Hasil positif yang diperoleh ditandai dengan terbentuknya zona lisis, atau plak yang jernih berbentuk bulat diantara bakteri yang tumbuh. Plak-plak tersebut menandakan adanya faga yang melisiskan sel inang sehingga sel inang mati. Plak ini kemudian dihitung untuk mengetahui kadar faga dalam contoh dan kemudian menyimpannya sebagai hasil dari penyaringan dan penggunaan jangka panjang. Metode uji plak ini dianggap sebagai metode baku (gold standar) untuk mengisolasi isolasi faga (Anderson et al., 2011).

Biakan murni E. coli dibiakkan ke dalam $10 \mathrm{ml}$ LB cair dan diinkubasi selama tiga jam pada suhu $37{ }^{\circ} \mathrm{C}$. Biakan ini digunakan sebagai pelapis dalam metode uji plak (Saefunida et al., 2016; Yulinery \& Triana, 2016).

Sebanyak 0,1 ml Filtrat II diencerkan secara desimal menggunakan Phosphate Buffer Saline ${ }^{\circledR}$ (PBS, Oxoid) murni hingga $10^{-8}$. Sebanyak $0,1 \mathrm{ml}$ dari masing-masing pengenceran diambil dan ditambahkan ke $0,5 \mathrm{ml}$ biakan E. coli dan diinkubasi selama 10 menit dalam penangas air bersuhu $30{ }^{\circ} \mathrm{C}$. Kontrol negatif dibuat hanya menggunakan suspensi biakan murni $E$. coli saja tanpa filtrat faga. Masing-masing perlakuan dituang ke dalam tujuh mililiter soft agar LB saat hangat-hangat kuku $\left(45{ }^{\circ} \mathrm{C}\right)$, diratakan suspensinya menggunakan vorteks, dan dituangkan ke atas media LB padat. Media didiamkan kurang lebih 30 menit pada suhu ruang $\left(30{ }^{\circ} \mathrm{C}\right)$ hingga seluruh media memadat. Seluruh media diinkubasi dengan posisi terbalik pada suhu $35^{\circ} \mathrm{C}$ selama 48 jam untuk pengamatan plak faga (Saefunida et al., 2016). Plak yang terbentuk dicongkel dengan menggunakan öse suci hama dan dimasukkan ke tabung sentrifus yang berisi satu mililiter larutan PBS. Suspensi tersebut disentrifugasi pada kecepatan $3000 \mathrm{rpm}$ selama 10 menit. Supernatan diambil dan disimpan di dalam tabung dan ditambahkan sebanyak satu 
tetes klorofom per satu miliiter PBS. Tabung disimpan pada suhu $4{ }^{\circ} \mathrm{C}$ (Damayanti et al., 2016).

\section{HASIL}

\section{Isolasi $E$. coli}

Bakteri E. coli berhasil diisolasi dan dikukuhkan positif pada semua contoh air yang diuji dan memiliki densitas sebesar $10 \mathrm{CFU} / \mathrm{ml}$ pada air ikan hidup, $10^{3} \mathrm{CFU} / \mathrm{ml}$ pada ketiga air Sungai Ciliwung dan air minum hewan, serta $10^{6}$ CFU/ml pada air celupan daging Pasar Merdeka Kota Bogor. Bakteri E. coli bersifat negatif Gram, mampu bergerak dan berbentuk kokobasil. Bakteri ini menghasilkan indol dan asam organik. Bakteri memfermentasi laktosa dan tidak memfermentasi sitrat.

\section{Keberadaan Plak}

Plak faga ditemukan pada contoh air celupan daging Pasar Merdeka Kota Bogor seperti yang disajikan pada Gambar 1.

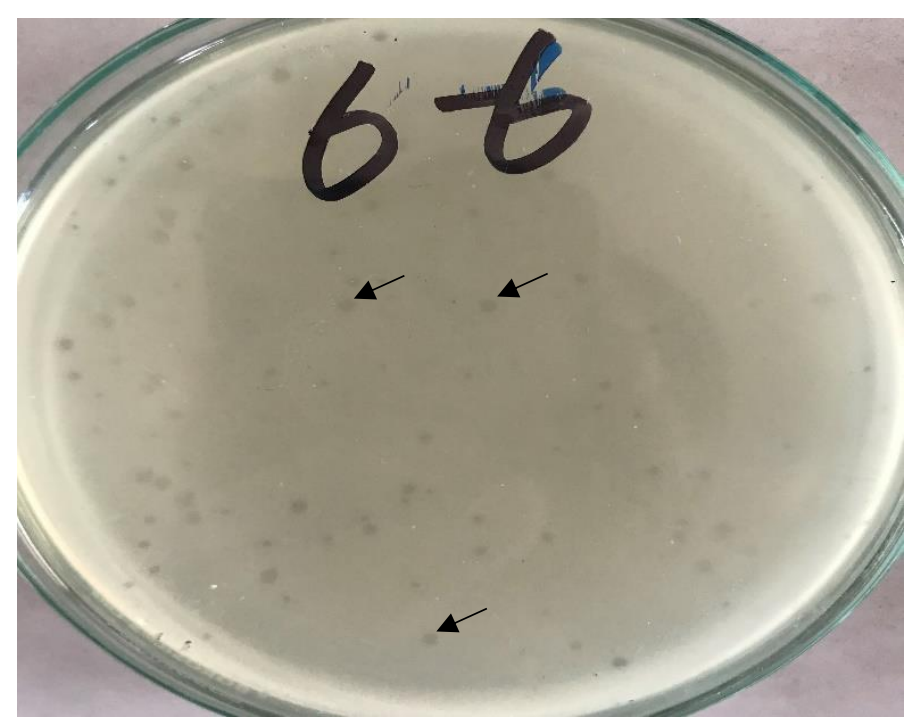

Gambar 1. Plak faga (ditunjukkan oleh tanda panah) yang diperoleh dari contoh air celupan daging

Jumlah plak, atau zona lisis pada isolat bakteri di cawan agar yang terdapat pada air celupan daging Pasar Merdeka Kota Bogor dihitung dengan rumus sebagai berikut (Budiarti \& Rusmana 2018): $\begin{aligned} \text { Kadar Faga }(P F U / m l)= & \text { Jumlah plak } \times 10 \times \text { kebalikan } \\ & \text { faktor pengenceran }\end{aligned}$

Kadar virus dihitung menggunakan rumus yang sudah ada. Berdasarkan perhitungan dari 91 jumlah plak pada pengenceran $10^{-6}$ maka kadar faga sebesar $9,1 \times 10^{8} \mathrm{PFU} / \mathrm{ml}$.

\section{PEMBAHASAN}

Faga merupakan virus yang menginfeksi bakteri. Faga memiliki siklus hidup yang bersifat litik dan lisogenik (Clokie et al., 2011). Siklus hidup litik menyebabkan lisisnya sel bakteri yang diinfeksinya dalam bentuk plak, atau bercak pada cawan agar. Siklus hidup lisogenik tidak melisiskan bakteri inang melainkan menyatu dengan kromosom sel inang seperti pada temperate phages lamda yang memiliki siklus hidup litik dan lisogenik. Perubahan siklus lisogenik faga ke siklus litik (maupun sebaliknya) dapat terjadi dengan sendirinya, atau dipicu oleh beberapa faktor luar, seperti perubahan nutrisi sel inang; $\mathrm{pH}$ atau suhu; dan paparan terhadap antibiotika, hidrogen peroksida, DNA asing dan agen-agen perusak DNA sel inang (HowardVarona et al. 2017). Dalam Penelitian ini, faga $E$. coli berhasil diisolasi hanya pada air celupan daging Pasar Merdeka Kota Bogor yang tingkat kekeruhan airnya sangat tinggi dibandingkan dengan contoh air lainnya. Keberhasilan mendapatkan faga dari contoh air tersebut juga berhubungan dengan kepadatan bakteri E. coli yang cukup tinggi, yaitu $10^{6} \mathrm{CFU} / \mathrm{ml}$. Pada beberapa contoh air yang diduga kemungkinan mengandung faga, tetapi hasilnya tidak bisa mempertegas keberadaan faga karena ciri-ciri plak yang dimiliki kurang jelas, atau bentuknya yang kecil seperti pada depot air minum dan airair sungai yang jernih yang biasanya memiliki jumlah sel inang faga yang sedikit. Faga dengan kadar $10^{6} \mathrm{PFU} / \mathrm{ml}$, atau kurang pada uji plak biasanya tidak memiliki plak, atau plak yang terdapat kurang jelas dan kecil (Mirzaei \& Nilsson, 2015).

Hal lain yang menjadi penyebab tidak adanya plak, selain keberadaan faga yang bersifat lisogenik dan kadar yang rendah, adalah 
terjadinya ketahanan bakteri terhadap faga. Penelitian Moons et al. (2013) mendapatkan adanya ketahanan lapisan hayati (biofilms) E. coli terhadap faga litik T7 yang menyebabkan tidak lisisnya sel bakteri pada cawan agar. Ketahanan terhadap faga litik terjadi karena perubahan mutasi sel bakteri yang menghasilkan kapsul polisakarida yang berlebih di tempat pelekatan faga dengan sel bakteri inang sehingga menghambat penempelan faga terhadap permukaan sel bakteri. Ketika faga menginfeksi sel inang, faga juga menghadapi berbagai teknik antivirus dari bakteri seperti mencegah jalan penyerapan faga, mencegah masuknya DNA faga, memotong asam nukleat faga, dan bentuk infeksi yang gagal (Labrie et al., 2010). Hasil Penelitian ini menyampaikan bahwa terdapat faga E. coli pada contoh air celupan daging Pasar Merdeka Kota Bogor dengan kadar yang cukup tinggi $\left(10^{8}\right)$ yang dapat disimpan dan digunakan sebagai alternatif pengganti antibiotika untuk infeksi yang diakibatkan oleh E. coli.

Isolasi faga umumnya dilakukan untuk mendapatkan faga yang virulen, yaitu faga yang bersifat litik dan memiliki kisaran inang yang luas yang dapat melisiskan beberapa galur bakteri. Hal ini berkaitan dengan salah satu syarat dalam terapi faga terhadap infeksi bakteri selain menggunakan antimikroba (Hyman, 2019). Keefektifan penggunaan terapi faga dalam menyembuhkan penyakit yang disebabkan oleh bakteri telah dibuktikan dalam beberapa penelitian baik pada manusia maupun hewan yang disebabkan oleh bakteri-bakteri patogen seperti Staphylococcus, Pseudomonas, Klebsiella, E. coli, dan lain-lain (Lin et al., 2017). Penggunaan faga sebagai terapi biasanya digunakan dalam bentuk koktail yang terdiri atas beberapa galur faga yang sudah dimurnikan dan/atau bersamaan dengan penggunaan antimikroba yang disuntikkan ke pembuluh darah vena untuk kematian jumlah bakteri yang maksimal (Lin et al., 2017). Syarat lainnya dalam penggunaan faga sebagai terapi adalah faga yang diisolasi memiliki kemampuan menurunkan jumlah lapisan hayati (biofilms). Saefunida et al. (2016) menemukan bahwa faga khusus E. coli yang diisolasi dari air minum isi ulang mampu menurunkan lapisan hayati E. coli sehingga hal ini menunjukkan bahwa faga $E$. coli dapat dijadikan alternatif sebagai anti lapisan hayati dalam menurukan jumlah bakteri patogen.

\section{SIMPULAN}

Ditemukan E. coli pada contoh air Sungai Ciliwung 1, air Sungai Ciliwung 2, air Sungai Ciliwung 3, air minum hewan, air ikan hidup, dan air celupan daging Pasar Merdeka Kota Bogor. Faga hanya terdapat pada contoh air celupan daging dari Pasar Merdeka dengan kadar 9,1 x $10^{8}$ $\mathrm{PFU} / \mathrm{ml}$.

\section{UCAPAN TERIMA KASIH}

Penulis mengucapkan terima kasih kepada bapak Agus Somantri dari Divisi Mikrobiologi Fakultas Kedokteran Hewan Institut Pertanian Bogor yang telah membantu selama penulis mengerjakan Penelitian ini.

\section{KEPUSTAKAAN}

Ackermann HW. 2012. Bacteriophage electron microscopy. Advances in Virus Research 82:132.doi.org/10.1016/B978-0-12-3946218.00017-0.

Anderson B, Rashid MH, Carter C, Pasternack G, Rajanna C, Revazishvili T, Dean T, Senecal A, Sulakvelidze A. 2011. Enumeration of bacteriophage particles. Bacteriophage 1(2):8693.doi:10.4161/bact.1.2.15456.

Budiarti S, Rusmana I. 2018. Eksplorasi dan karaterisasi bakteriofag. Bogor (ID): IPB Press. Edisi Pertama.

Chan BK, Abedon ST, Loc-Carrillo C. 2013. Phage cocktails and the future of phage therapy. Future Microbial 8(6):769783.doi:10.2217/fmb.13.47.

Clokie MR.J, Millard AD, Letarof AV, Heaphy S. 2011. Phages in nature. Bacteriophage 1(1):31-45.doi:10.4161/bact.1.1.14942.

Damayanti R, Jannah SN, Wijanarka, Wijanarka, Rahaju SH. 2016. Isolasi faga Salmonella spp. 
dari biofilm pada sistem air minum isi ulang. Jurnal Akademika Biologi 5(2):59-67.

Howard-Varona C, Hargreaves KR, Abedon ST, Sullivan MB. 2017. Lysogeny in nature: mechanism, impact, and ecology of temperate phages. The ISME Journal 11:15111520.doi:10.1038/ismej.2017.16.

Hyman P. 2019. Phages for phage therapy: isolation, characterization, and host range breadth. Pharmaceuticals 1:1235.doi:10.3390/ph12010035.

Kartikasari AM, Hamid IS, Purnama MTE, Damayanti R, Fikri F, Praja RN. 2019. Isolasi dan identifikasi bakteri Escherichia coli kontaminan pada daging ayam broiler di rumah potong ayam Kabupaten Lamongan. Jurnal Medik Veteriner 2(1):6671.doi:10.20473/jmv.vol2.iss1.2019.66-71.

Labrie SJ, Samson JE, Moineau S. 2010. Bacteriophage resistance meschanism. Nature reviews 8:317-326.doi: 10.1038/nrmicro2315.

Lin DM, Koskella B, Lin HC. 2017. Phage therapy: an alternative to antibiotics in the age of multi-drug resistance. World Journal of Gastrointestinal Pharmacology and Therapeutics $\quad \mathbf{8 ( 3 )}$ :162173.doi:10.4292/wjgpt.v8.i3.162.

Moons P, Faster D, Aertsen A. 2013. Lysogenic conversion and phage resistance development in phage exposed E. coli biofilms. Viruses 5:150-161.doi:10.3390/v5010150.

Mirzaei MK, Nilsson AS. 2015. Isolastion of phages for phage therapy: a comparison of spot tests and efficiency of plating analysis for determination of host range and efficacy. Plos One

10(3):e0118557.doi:10/1371.journal.pone.011 8857.

O'Neill J. 2014. Antimicrobial Resistance: Tackling a crisis for the health and wealth of nations. London: Review on Antimicrobial Resistance. [Internet] Tersedia pada https://amr-review.org/sites/default/files/ AMR\%20Review\%20Paper\%20\%20Tackling $\% 20 \mathrm{a} \% 20$ crisis $\% 20$ for $\% 20$ the $\% 20$ health $\% 20$ and $\% 20$ wealth $\% 20 \mathrm{of} \% 20$ nations_1.pdf

Diakses pada tanggal 11 November 2018.
Rahaju SH. 2014. Metoda pengkayaan, filtrasi dan pertumbuhan untuk isolasi bateriofag spesifik Salmonella typhimurium pada sampel air. Prosiding Seminar Nasional Penelitian dan PKM: Sains, Teknologi, dan Ilmu Kesehatan, Bandung: 29 Oktober 2014. Vol. 4(1). Hal. 415-422.

Saefunida DS, Wijanarka, Rukmi M.GI, Hidayat NN. 2016. Isolasi bakteriofag Escherichia coli dari sistem distribusi air minum isi ulang sebagai antibiofilm. Jurnal Akademika Biologi 5(2):68-75.

Triana E. 2018. Aktivitas antibiofilm bakteri escherichia coli oleh bakteriofag secara in vitro. Berita Biologi 17(1):7784.doi:10.14203/beritabiologi.v17i1.3234.

Ulfah NF, Erina, Darniati. 2017. Isolasi dan identifikasi Escherichia coli pada ayam panggang di beberapa rumah makan di Kecamatan Syiah Kuala Kota Banda Aceh. Jurnal Ilmiah Mahasiswa Veteriner 1(3):383390.

Utami ER. 2012. Antibiotika, resistensi, dan rasionalitas terapi. Sainstis 1(1):124138.doi:10.18860/elha.v1i4.1783.

[WHO] World Health Organization. 2014. Antimicrobial Resistance: global report on surveillance 2014. WHO.

Yulinery T, Triana E. 2016. Teknik pengkayaan isolasi bakteriofag Salmonella sp. sebagai agen kontrol terapi infeksi bakteri. Prosiding Seminar Nasional II Tahun 2016, Malang: 26 Maret 2016. Hal. 1264-1273. 